\title{
IDENTIFIKASI INDEKS KENYAMANAN KOTA YOGYAKARTA BERDASARKAN KRITERIA CULTURAL HERITAGE
}

\author{
Identification of Liveable Index of Yogyakarta based on Cultural \\ Heritage Criteria
}

\author{
Ayu Candra Kurniati ${ }^{1}$, Fahril Fanani²
}

Diterima: 2 Oktober 2018 Disetujui: 23 November 2018

\begin{abstract}
Abstrak: Kota Yogyakarta merupakan kota dengan nilai index liveable city tertinggi di Indonesia dengan nilai index $68.14 \%$ untuk kriteria kehidupan sosial dan $70.89 \%$ untuk kriteria perlindungan bangunan bersejarah. Mengingat misi Kota Yogyakarta adalah untuk meningkatkan kualitas budaya dan memperkuat moral, etika serta budaya masyarakat, maka perlu dilakukan kajian indeks kenyamanan berdasarkan kriteria cultural heritage. Penelitian ini menggunakan pembobotan data dikotomi, dengan variabel: perubahan fungsi dan bentuk, status kepemilikan dan penggunaan BCB (bangunan cagar budaya) serta jumlah BCB yang dihancurkan dan/atau dalam proses penghancuran. Hasil yang diperoleh adalah nilai indeks kenyamanan Kota Yogyakarta untuk kriteria pelestarian BCB tertinggi berada di kawasan cagar budaya Kotabaru (72\%), kemudian kawasan cagar budaya Pakualaman (65\%), kawasan cagar budaya Kraton (64,3\%), selanjutnya kawasan cagar budaya Malioboro (64\%) dan terendah adalah kawasan cagar budaya Kogede $(60,6 \%)$. Kawasan cagar budaya Kotabaru memiliki indeks kenyamanan tertinggi karena sebanyak $100 \%$ BCB tidak mengalami perubahan bentuk, 40\% BCB mengalami perubahan fungsi, 20\% BCB merupakan milik pribadi, 100\% BCB dipergunakan untuk kelompok/umum dan 100\% BCB tidak dihancurkan dan/atau dalam proses penghancuran sehingga bentuk asli $\mathrm{BCB}$ masih dipertahankan. Kesimpulan yang diperoleh adalah keberadaan bangunan cagar budaya di suatu kota akan menambah nilai identitas lingkungan yang merupakan penciri kawasan dan karakteristik masyarakat yang tinggal didalamnya.
\end{abstract}

Kata Kunci: indeks kenyamanan, bangunan cagar budaya, kawasan cagar budaya, identitas kota

Abstract: Yogyakarta is the livable city in Indonesia with the highest index score, $68.14 \%$ for social life and $70.89 \%$ for the preservation of cultural heritage building. Considering the mission of Yogyakarta is to enhance cultural quality and strengthen morality, behavior and cultural value of the community, it is considerable to conduct a research regarding to livable city index in Yogyakarta based on the criteria of cultural heritage. Furthermore, this research used scoring dichotomy data as a methodology with variables: the changes in building's form and function, the ownership status and the usage of cultural heritage building, as well as the amount of cultural heritage buildings that have been demolished and/or in the process of demolition. The results show the highest livable index for preservation of cultural heritage building is in cultural preservation area Kotabaru (70\%), followed by Pakualaman (65\%), Kraton (64.3\%), Malioboro (64\%) and the least is Kogede (60.6\%). Kotabaru

\footnotetext{
${ }^{1}$ Jurusan Perencanaan Wilayah dan Kota, Sekolah Tinggi Teknologi Nasional
} 
has the highest livable index due to from the total percentage, $100 \%$ of the buildings are in the original form, $40 \%$ have its function changed, $20 \%$ are in personal ownership, $100 \%$ are in group/association, and $100 \%$ are not demolished. The conclusion of this study is that the existence of cultural heritage building in the city will increase the value of environmental identity which is resembles the character of the area and the community within.

Key words: livable index, cultural heritage building, cultural heritage area, city identity

\section{PENDAHULUAN}

Perencanaan kota ideal, sejatinya adalah gabungan antara konsep liveable city dan sustainable city dimana suatu kota mampu untuk menciptakan kondisi lingkungan kota yang mempertahankan kualitas hidup yang dibutuhkan oleh masyarakat kota saat ini maupun masa depan, sehingga menimbulkan suasana kota yang nyaman sebagai tempat tinggal dilihat dari berbagai aspek fisik maupun non fisik (Darise, Tondobala, dst. 2015); (Wheeler, 2004). Kenyamanan sosial (non fisik) adalah kondisi terpenuhinya kebutuhan dasar dalam melakukan interaksi sosial yang nyaman serta melibatkan ruang dan waktu tertentu, dimana kebutuhan dasar diartikan sebagai kebutuhan spasial yakni stimulasi, keamanan dan identitas (Wirastari, Suprihardjo, 2012). Identitas lingkungan dapat dipengaruhi oleh sosial budaya yang merupakan penciri ruang. Hubungan sosial dan identitas menimbulkan rasa yang kuat dengan kawasan permukiman memberikan keinginan yang kuat untuk selalu menetap pada kawasan tersebut

Muttaqin (2010) menjelaskan bahwa terdapat 25 kriteria kota layak huni yang dirilis oleh Ikatan Ahli Perencanaan Indonesia (IAP) yang berpedoman pada variable utama perkotaan berupa fisik kota, kualitas lingkungan, transportasi-aksesibilitas, fasilitas, utilitas, ekonomi dan sosial. Diantara ke-25 kriteria tersebut, scope penelitian ini berfokus pada kriteria perlindungan bangunan bersejarah. Dalam mengkaji tingkat kenyamanan kota besar di Indonesia, IAP melakukan penilaian kota layak huni (liveable city) dan baru dilakukan di beberapa kota besar di Indonesia. Menurut IAP (2014), Kota Yogyakarta merupakan salah satu kota dengan nilai index liveable city tertinggi di Indonesia dengan nilai index $68.14 \%$ untuk kriteria kehidupan sosial dan $70.89 \%$ untuk kriteria perlindungan bangunan bersejarah. Berdasarkan Dinas Pariwisata dan Kebudayaan Kota Yogyakarta tahun 2017, Kota Yogyakarta memiliki 212 Bangunan Cagar Budaya (BCB) yang tersebar di lima Kawasan Cagar Budaya (KCB), yaitu KCB Kotabaru, KCB Kotagede, KCB Malioboro, KCB Kraton dan KCB Pakualaman. Bangunan cagar budaya adalah susunan binaan yang terbuat dari benda alam atau benda buatan manusia untuk memenuhi kebutuhan ruang berdinding dan/atau tidak berdinding, dan beratap (Perda DIY Nomor 6 Tahun 2012).

Kesadaran masyarakat dan pemerintah tentang pelestarian benda dan bangunan cagar budaya meningkat setiap tahun, tetapi kasus-kasus (pelanggaran) cagar budaya juga tetap ada (Marbun, 2012). Pelanggaran-pelanggaran yang sering terjadi antara lain perubahan bentuk bangunan cagar budaya, dan juga berbagai pelaksanaan pembangunan yang lepas konteks dengan lingkungan cagar budaya (Hadiyanta, 2015; Widyanto, 2016). Menilik dari berbagai permasalahan tersebut dan mengingat misi Kota Yogyakarta untuk meningkatkan kualitas budaya dan memperkuat moral, etika serta budaya masyarakat Kota Yogyakarta (Pemerintah Kota Yogyakarta, 2013), maka perlu dilakukan kajian indeks kenyamanan Kota Yogyakarta berdasarkan kriteria cultural heritage.

Cultural heritage (warisan budaya) yang dimaksud dalam penelitian adalah bangunan cagar budaya. Bangunan cagar budaya adalah susunan binaan yang terbuat dari benda alam maupun buatan manusia untuk memenuhi kebutuhan ruang berdinding dan/atau tidak berdinding dan beratap. Variabel yang dipergunakan adalah gabungan antara variabel pelestarian (Pergub DIY No 62 Tahun 2013) dan variabel kenyamanan kota berdasarkan kriteria cultural heritage (Bell, 2000); (Tan, Thye. etc. 2014), seperti pada tabel berikut. 
Tabel 1. Pemilihan Variabel Penelitian

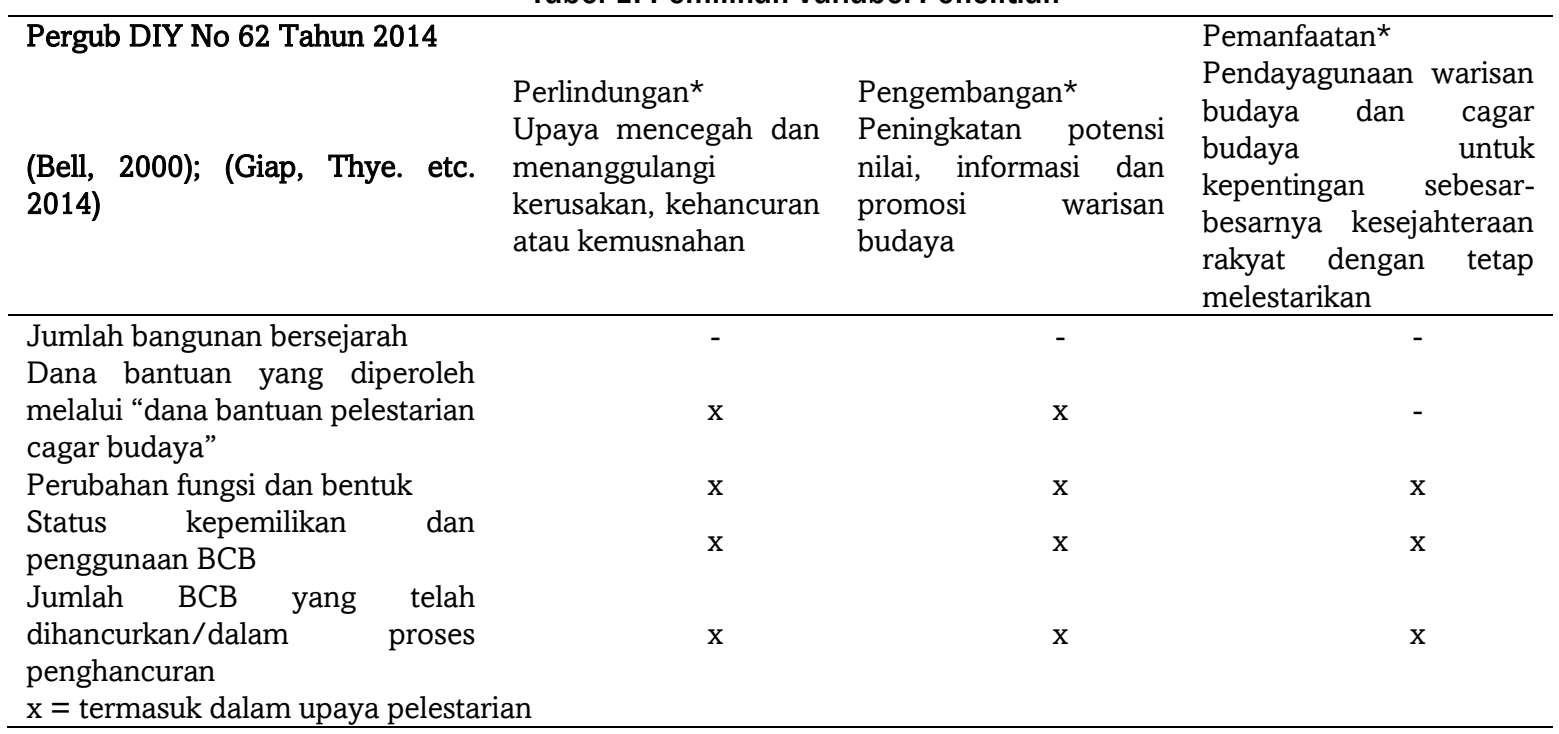

Sumber: Peneliti, 2018

Berdasarkan tujuan penelitian, keterbatasan data serta cakupan wilayah penelitian yang cukup luas, maka variabel penelitian yang dipilih adalah perubahan fungsi dan bentuk BCB, status kepemilikan BCB dan jumlah BCB yang telah dihancurkan dan/atau dalam proses penghancuran di tahun 2017-2018

Penelitian ini dilakukan di lima Kawasan Cagar Budaya Kota Yogyakarta berdasarkan SK Gubernur Yogyakarta No 10 Tahun 2012 tentang Pelestarian Warisan Budaya dan Cagar Budaya, yaitu di KCB Malioboro, KCB Pakualaman, KCB Kotagede, KCB Kraton dan KCB Kotabaru. Peta wilayah studi terdapat pada Gambar 1.

\section{METODE}

Tujuan penelitian ini adalah untuk menilai index kenyamanan berdasarkan kriteria pelestarian bangunan cagar budaya. Penelitian ini menggunakan pendekatan penelitian deskriptif kuantitatif karena dalam pelaksanaannya meliputi data statistik biner yang diperoleh dari survey sekunder. Data biner/dikotomi (Sujarweni, 2015) adalah variabel yang hanya mempunyai dua kategori saja, yaitu yang menyatakan kejadian sukses $(\mathrm{Y}=1)$ dan yang menyatakan kejadian gagal $(\mathrm{Y}=0)$, dengan asumsi semakin tinggi hasilnya maka semakin tinggi nilai index kenyamanan kota terhadap cultural heritage (Bell, 2000). Hasil dari pengumpulan data akan diolah menggunakan Microsoft Excel untuk mengetahui frekuensi dan presentasenya. Kemudian hasil pengolahan tersebut akan dianalisis menggunakan analisis statistik deskriptif.

Data primer dikumpulkan langsung di lokasi studi dengan melakukan observasi dan kuisioner. Observasi dilakukan untuk melakukan pengamatan langsung terhadap kondisi bangunan bersejarah dan penggunaan fungsi dari bangunan bersejarah, sedangkan kuisioner dilakukan untuk mengetahui upaya pelestarian masyarakat terhadap bangunan bersejarah dan perubahan fungsi yang telah dilakukan. Responden untuk kuisioner adalah sampel dari pemilik bangunan cagar budaya yang terdata pemerintah Kota Yogyakarta, yaitu sebanyak 68 responden. Sedangkan untuk data sekunder dikumpulkan dari berbagai sumber, dengan rincian pada Tabel 1. 


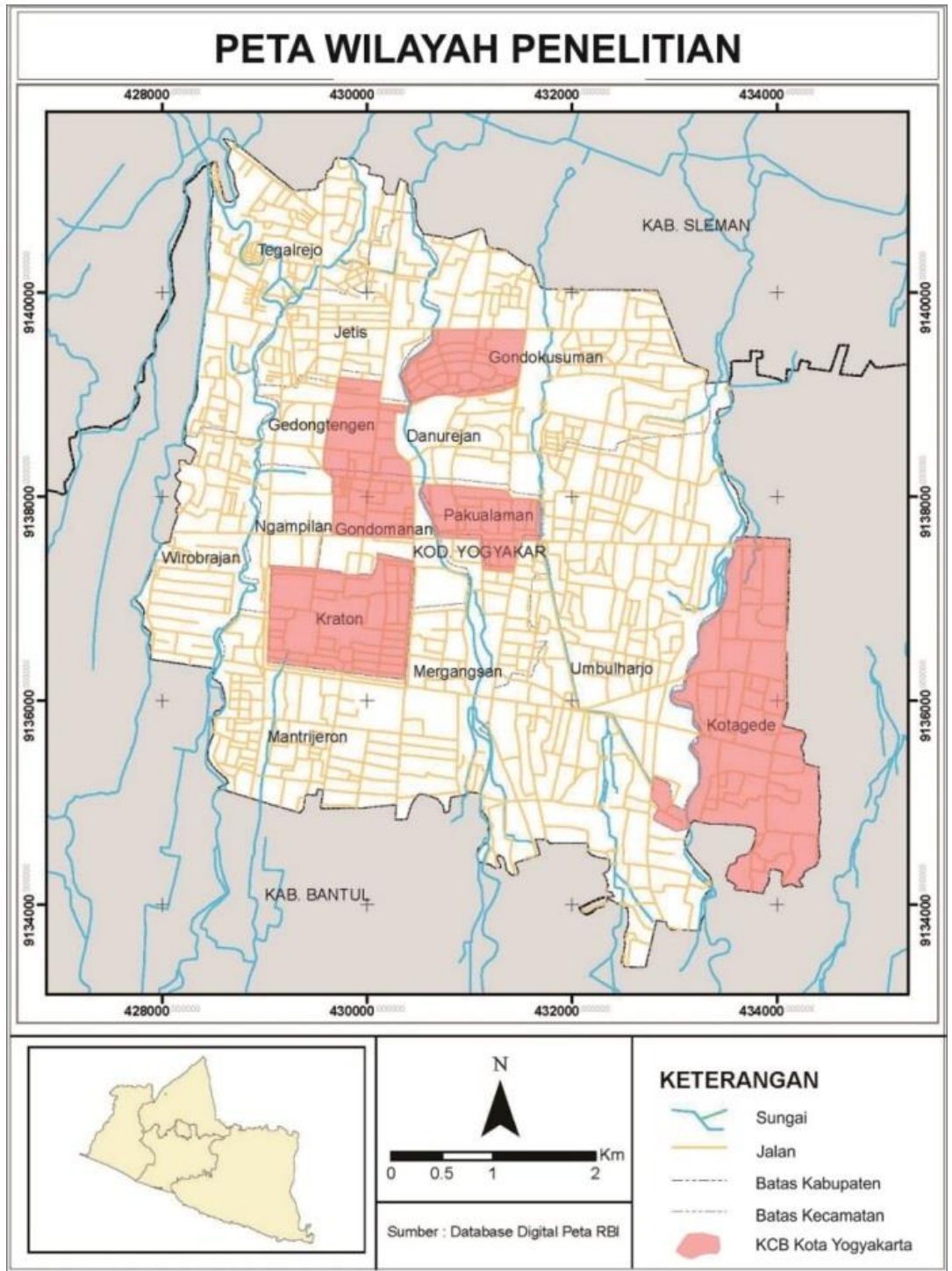

Sumber: Dinas Kebudayaan Kota Yogyakarta

\section{Gambar 1. Peta Wilayah Penelitian}

Tabel 1. Kebutuhan Data Sekunder

\begin{tabular}{lll}
\hline No & \multicolumn{1}{c}{ Jenis Data } & \multicolumn{1}{c}{ Sumber } \\
\hline 1 & Data perubahan fungsi dan bentuk bangunan bersejarah & Pemerintah Kota Yogyakarta \\
2 & Status kepemilikan bangunan cagar budaya & Pemerintah Kota Yogyakarta \\
3 & $\begin{array}{l}\text { Data jumlah bangunan cagar budaya yang } \\
\text { telah dihancurkan atau dalam proses penghancuran }\end{array}$ & Pemerintah Kota Yogyakarta \\
4 & $\begin{array}{l}\text { Data jumlah bangunan bersejarah yang terdaftar dalamPemerintah Kota Yogyakarta } \\
\text { bangunan cagar budaya }\end{array}$ & \\
5 & $\begin{array}{l}\text { Data kegiatan preservasi bangunan bersejarah yang dilakukanPemerintah Kota Yogyakarta } \\
\text { pemerintah }\end{array}$
\end{tabular}

Sumber: Peneliti, 2018

Penelitian ini mempergunakan sampel untuk penyebaran kuisioner dan pemilihan bangunan cagar budaya. Pengambilan sampel dilakukan karena besarnya populasi jumlah 
bangunan yang ditetapkan menjadi bangunan cagar budaya Kota Yogyakarta, yaitu 212 bangunan cagar budaya, dengan rincian: KCB Kotabaru 16 BCB, KCB Malioboro 32 BCB, KCB Pakualaman 21 BCB, KCB Kraton 43 BCB, dan KCB Kotagede 96 BCB. Pada penelitian ini, teknik pengambilan sampel yang digunakan adalah dengan probability sampling, yaitu teknik pengambilan sampel yang memberikan peluang yang sama kepada setiap anggota populasi untuk menjadi sampel. Cara yang dilakukan untuk pengambilan sampel adalah Proportioate Stratified Random Sampling (pengambilan sampel secara bertingkat).

Jumlah ukuran sample menggunakan rumus Slovin, dengan kesalahan (presisi) adalah $10 \%$. Sehingga jumlah sampel yang diperoleh adalah 67,97 (68 sampel), dengan rincian: KCB Kotabaru 5 BCB, KCB Malioboro 10 BCB, KCB Pakualaman 8 BCB, KCB Kraton14 BCB, dan KCB Kotagede $31 \mathrm{BCB}$ dengan total sampel adalah 68 sampel.

Penelitian ini menggunakan data biner/dikotomi (Sujarweni, 2015) sebagai data penelitian untuk menghitung index kenyamanan Kota Yogyakarta. Data biner/dikotomi adalah variabel yang hanya mempunyai dua kategori saja, yaitu yang menyatakan kejadian sukses $(\mathrm{Y}=1)$ dan yang menyatakan kejadian gagal $(\mathrm{Y}=0)$, dengan asumsi semakin tinggi hasilnya maka semakin tinggi nilai index kenyamanan kota terhadap pelestarian cultural heritage (Bell, 2000); (Pergub DIY, 2013); (Wahyudi, 2015); (Undang-Undang Nomor 5, 1992). Sehingga apabila kegiatan yang dilakukan menambah dan/atau memberikan dampak positif terhadap kegiatan pelestarian bernilai 1 (sukses), sedangkan apabila mengurangi dan/atau memberikan dampak negatif terhadap pelestarian bernilai 0 (gagal), dengan rincian penjelasan sebagai berikut:

1. Variabel Perubahan Bentuk, apabila TIDAK-Sukses (nilai 1) terjadi perubahan bentuk pada $\mathrm{BCB}$ maka nilai index kenyamanan akan semakin rendah, karena hal ini mempengaruhi pelestarian bangunan dimana pada BCB tidak diperbolehkan mengubah bentuk bangunan, kecuali dilakukan pemugaran untuk alasan pelestarian

A. YA berubah bentuk (0)

B. TIDAK berubah bentuk (1)

2. Variabel Perubahan Fungsi, apabila YA-Sukses (nilai 1) terjadi perubahan fungsi pada BCB maka nilai index kenyamanan akan semakin tinggi, karena hal ini tidak mempengaruhi pelestarian bangunan selama tidak merubah bentuk bangunan. Selain itu, dengan merubahnya fungsi bangunan diharapkan dapat menambah upaya pelindungan, peningkatan potensi bangunan (pengembangan) dan menambah pemanfaatan bangunan yang dapat meningkatkan kesejahteraan masyarakat
A. YA berubah fungsi (1)
B. TIDAK berubah fungsi (0)

3. Variabel Status Kepemilikan, apabila YA-Sukses (nilai 1) milik PRIBADI maka nilai index kenyamanan akan semakin tinggi, karena dengan milik pribadi maka semakin tingginya keterkaitan dan keterikatan pemilik bangunan cagar budaya dengan tetap melaksanakan kewajiban sebagai pemilik bangunan cagar budaya yaitu dengan tetap melestarikan sesuai peraturan pelestarian yang berlaku. Kepedulian terhadap bangunan cagar budaya yang dimiliki baik oleh pemerintah dan utamanya milik pribadi, berarti merupakan potensi awal dalam upaya menuju tekad nasional melestarikan budaya bangsa.
A. YA - pribadi (1)
B. TIDAK - sewa (0) 
4. Variabel Penggunaan Bangunan, apabila TIDAK-Sukses (nilai 1) digunakan pribadi/perorangan maka nilai index kenyamanan akan semakin tinggi, karena dengan digunakan kelompok maka dalam membiayai perawatan dan pemeliharaan bangunan cagar budaya akan lebih mudah mengingat mahalnya biaya pelestarian. Hal ini juga merupakan permasalahan tersendiri bagi pemilik bangunan rumah tinggal yang notabene merupakan pengguna tunggal/pribadi. Penggunaan personal/pribadi merupakan bangunan dengan fungsi tempat tinggal, sedangkan kelompok dapat berfungsi sebagai restaurant dan fasilitas umum (yang dipergunakan bersama/umum)
A. YA- pribadi/perorangan (0)
B. TIDAK-kelompok (1)

5. Variabel jumlah bangunan cagar budaya yang dihancurkan atau dalam proses pengancuran, apabila YA-Gagal (0) bangunan dalam proses dan/atau telah dihancuran, maka nilai index kenyamanan akan semakin berkurang karena menunjukkan kurangnya upaya pelestarian terhadap bangunan cagar budaya.

A. YA bangunan dihancurkan/dalam proses penghancuran (0)

B. TIDAK dihancurkan/dalam proses penghancuran (1)

\section{HASIL DAN PEMBAHASAN}

Penelitian ini menggunakan metode skoring yang dilakukan menggunakan data dikotomi/biner dengan skor/bobot 0 untuk jawaban TIDAK dan 1 untuk jawaban IYA dengan total nilai bobot tersebut akan menentukan nilai index kenyamanan kota Yogyakarta dari kriteria pelestarian cagar budaya. Data yang diperoleh dari hasil survey primer menggunakan kuesioner sebagai alat pengumpulan data yang dibagikan ke 68 responden yang merupakan pemilik dan/atau pengguna bangunan cagar budaya, dengan hasil sebagai berikut

Tabel 3. Pembobotan Variabel Kenyamanan berdasarkan Kriteria Pelestarian BCB

\begin{tabular}{|c|c|c|c|c|c|c|c|}
\hline \multirow[b]{2}{*}{ No } & \multirow[b]{2}{*}{$\mathrm{KCB}$} & \multirow[b]{2}{*}{ Kode } & \multicolumn{5}{|c|}{ Variabel Indeks Kenyamanan Berdasarkan Kriteria Pelestarian BCB } \\
\hline & & & $\begin{array}{l}\text { Perubahan } \\
\text { bentuk } \\
\text { bangunan }\end{array}$ & $\begin{array}{l}\text { Perubahan } \\
\text { fungsi } \\
\text { bangunan }\end{array}$ & $\begin{array}{l}\text { Status } \\
\text { kepemilikan } \\
\text { bangunan }\end{array}$ & $\begin{array}{l}\text { Statujs } \\
\text { penggunaan } \\
\text { bangunan }\end{array}$ & $\begin{array}{l}\text { Bcb yang } \\
\text { dihancurkan/ } \\
\text { proses } \\
\text { penghancuran }\end{array}$ \\
\hline 1 & \multirow{10}{*}{ Malioboro } & $\mathrm{A} 1$ & 1 & 0 & 0 & 1 & 1 \\
\hline 2 & & A2 & 1 & 1 & 0 & 1 & 1 \\
\hline 3 & & A4 & 1 & 0 & 0 & 1 & 1 \\
\hline 4 & & A5 & 1 & 0 & 0 & 1 & 1 \\
\hline 5 & & A6 & 1 & 0 & 0 & 1 & 1 \\
\hline 6 & & A8 & 1 & 0 & 0 & 1 & 1 \\
\hline 7 & & A11 & 1 & 0 & 0 & 1 & 1 \\
\hline 8 & & A12 & 1 & 0 & 1 & 1 & 1 \\
\hline 9 & & A13 & 1 & 0 & 0 & 1 & 1 \\
\hline 10 & & A15 & 1 & 0 & 0 & 1 & 1 \\
\hline \multicolumn{2}{|c|}{ TOTAL } & & 10 & 1 & 1 & 10 & 10 \\
\hline 16 & \multirow[t]{6}{*}{ Kotabaru } & B1 & 1 & 0 & 0 & 1 & 1 \\
\hline 17 & & B2 & 1 & 0 & 0 & 1 & 1 \\
\hline 18 & & B3 & 1 & 1 & 0 & 1 & 1 \\
\hline 19 & & B4 & 1 & 1 & 0 & 1 & 1 \\
\hline 20 & & B5 & 0 & 1 & 1 & 1 & 1 \\
\hline TOTAL & & & 5 & 2 & 1 & 5 & 5 \\
\hline 24 & \multirow[t]{5}{*}{ Pakualaman } & $\mathrm{C} 1$ & 1 & 0 & 1 & 0 & 1 \\
\hline 25 & & $\mathrm{C} 2$ & 1 & 1 & 1 & 0 & 1 \\
\hline 26 & & $\mathrm{C} 3$ & 1 & 0 & 0 & 1 & 1 \\
\hline 27 & & $\mathrm{C} 4$ & 1 & 0 & 1 & 0 & 1 \\
\hline 28 & & $\mathrm{C} 6$ & 1 & 0 & 1 & 0 & 1 \\
\hline
\end{tabular}




\begin{tabular}{|c|c|c|c|c|c|c|c|}
\hline \multirow[b]{2}{*}{ No } & \multirow[b]{2}{*}{$\mathrm{KCB}$} & \multicolumn{6}{|c|}{ Variabel Indeks Kenyamanan Berdasarkan Kriteria Pelestarian BCB } \\
\hline & & Kode & $\begin{array}{l}\text { Perubahan } \\
\text { bentuk } \\
\text { bangunan }\end{array}$ & $\begin{array}{l}\text { Perubahan } \\
\text { fungsi } \\
\text { bangunan }\end{array}$ & $\begin{array}{l}\text { Status } \\
\text { kepemilikan } \\
\text { bangunan }\end{array}$ & $\begin{array}{l}\text { Statujs } \\
\text { penggunaan } \\
\text { bangunan }\end{array}$ & $\begin{array}{l}\text { Bcb yang } \\
\text { dihancurkan/ } \\
\text { proses } \\
\text { penghancuran }\end{array}$ \\
\hline 29 & & $\mathrm{C} 7$ & 1 & 0 & 1 & 1 & 1 \\
\hline 30 & & C9 & 1 & 1 & 0 & 1 & 1 \\
\hline 31 & & $\mathrm{C} 10$ & 1 & 0 & 0 & 1 & 1 \\
\hline \multicolumn{2}{|c|}{ TOTAL } & & 8 & 2 & 4 & 4 & 8 \\
\hline 34 & \multirow[t]{15}{*}{ Kraton } & D1 & 1 & 0 & 0 & 1 & 1 \\
\hline 35 & & D2 & 1 & 0 & 0 & 1 & 1 \\
\hline 36 & & D3 & 1 & 0 & 0 & 1 & 1 \\
\hline 37 & & D4 & 1 & 0 & 0 & 1 & 1 \\
\hline 38 & & D6 & 0 & 0 & 0 & 1 & 1 \\
\hline 39 & & D7 & 1 & 0 & 0 & 0 & 1 \\
\hline 40 & & D8 & 1 & 1 & 0 & 1 & 1 \\
\hline 41 & & D9 & 1 & 0 & 1 & 0 & 1 \\
\hline 42 & & D11 & 1 & 0 & 1 & 1 & 1 \\
\hline 43 & & D12 & 1 & 1 & 1 & 1 & 1 \\
\hline 44 & & $\mathrm{D} 13$ & 1 & 0 & 0 & 0 & 1 \\
\hline 45 & & D14 & 1 & 0 & 0 & 1 & 1 \\
\hline 46 & & D16 & 1 & 0 & 1 & 1 & 1 \\
\hline 47 & & D21 & 1 & 0 & 1 & 0 & 1 \\
\hline \multicolumn{2}{|c|}{ TOTAL } & & 14 & 2 & 5 & 10 & 14 \\
\hline 55 & \multirow[t]{32}{*}{ Kotagede } & E1 & 1 & 0 & 1 & 0 & 1 \\
\hline 56 & & E2 & 1 & 0 & 1 & 0 & 1 \\
\hline 57 & & E3 & 1 & 0 & 1 & 0 & 1 \\
\hline 58 & & E4 & 1 & 0 & 1 & 0 & 1 \\
\hline 59 & & E5 & 1 & 0 & 1 & 0 & 1 \\
\hline 60 & & E6 & 1 & 0 & 1 & 0 & 1 \\
\hline 61 & & E7 & 1 & 0 & 1 & 0 & 1 \\
\hline 62 & & E8 & 1 & 0 & 1 & 0 & 1 \\
\hline 63 & & E9 & 1 & 1 & 0 & 1 & 1 \\
\hline 64 & & E10 & 1 & 1 & 1 & 1 & 1 \\
\hline 65 & & E11 & 1 & 0 & 1 & 0 & 1 \\
\hline 66 & & E12 & 1 & 0 & 1 & 1 & 1 \\
\hline 67 & & E13 & 1 & 0 & 0 & 1 & 1 \\
\hline 68 & & E16 & 1 & 0 & 1 & 0 & 1 \\
\hline 69 & & E19 & 0 & 0 & 1 & 0 & 1 \\
\hline 70 & & E20 & 1 & 0 & 0 & 1 & 1 \\
\hline 71 & & E21 & 1 & 0 & 1 & 0 & 1 \\
\hline 72 & & E22 & 1 & 0 & 1 & 0 & 1 \\
\hline 73 & & E23 & 1 & 0 & 1 & 0 & 1 \\
\hline 74 & & E24 & 1 & 0 & 1 & 0 & 1 \\
\hline 75 & & E25 & 1 & 0 & 0 & 1 & 1 \\
\hline 76 & & E26 & 1 & 0 & 1 & 0 & 1 \\
\hline 77 & & E27 & 1 & 0 & 1 & 0 & 0 \\
\hline 78 & & E28 & 1 & 0 & 1 & 0 & 1 \\
\hline 79 & & E29 & 0 & 0 & 1 & 0 & 1 \\
\hline 80 & & E30 & 0 & 0 & 1 & 0 & 1 \\
\hline 81 & & E34 & 0 & 0 & 1 & 0 & 1 \\
\hline 82 & & E35 & 1 & 1 & 1 & 0 & 1 \\
\hline 83 & & E36 & 1 & 0 & 1 & 0 & 1 \\
\hline 84 & & E38 & 1 & 0 & 0 & 1 & 1 \\
\hline 85 & & E42 & 1 & 0 & 1 & 1 & 1 \\
\hline \multicolumn{2}{|c|}{ TOTAL } & & 27 & 3 & 26 & 8 & 30 \\
\hline
\end{tabular}

Sumber: Hasil Analisis, 2018 
Tabel 4. Indeks Kenyamanan Kota Yogyakarta berdasarkan Kriteria Pelestarian BCB

\begin{tabular}{|c|c|c|c|c|c|c|c|c|}
\hline \multirow[b]{2}{*}{ No } & \multirow[b]{2}{*}{$\mathrm{KCB}$} & \multirow[b]{2}{*}{$\begin{array}{l}\text { Jumlah } \\
\text { Sample } \\
\text { Bangunan } \\
\text { Cagar } \\
\text { Budaya }\end{array}$} & \multicolumn{6}{|c|}{ Variabel Indeks Kenyamanan Berdasarkan Kriteria Pelestarian BCB } \\
\hline & & & Normalisasi & $\begin{array}{l}\text { Perubahan } \\
\text { Bentuk } \\
\text { Bangunan }\end{array}$ & $\begin{array}{l}\text { Perubahan } \\
\text { Fungsi } \\
\text { Bangunan }\end{array}$ & $\begin{array}{l}\text { Status } \\
\text { Kepemilikan } \\
\text { Bangunan }\end{array}$ & $\begin{array}{l}\text { Statujs } \\
\text { Penggunaan } \\
\text { Bangunan }\end{array}$ & $\begin{array}{l}\text { Bcb Yang } \\
\text { Dihancurkan/ } \\
\text { Proses } \\
\text { Penghancuran }\end{array}$ \\
\hline 1 & Malioboro & 10 & 3.1 & 10 & 1 & 1 & 10 & 10 \\
\hline 2 & Kotabaru & 5 & 6.2 & 5 & 2 & 1 & 5 & 5 \\
\hline 3 & Pakualaman & 8 & 3.88 & 8 & 2 & 4 & 4 & 8 \\
\hline 4 & Kraton & 14 & 2.21 & 14 & 2 & 5 & 10 & 14 \\
\hline 5 & Kotagede & 31 & 1 & 27 & 3 & 26 & 8 & 30 \\
\hline Total & & 68 & & 64 & 10 & 37 & 37 & 67 \\
\hline
\end{tabular}

Sumber: Hasil Analisis, 2018

Tabel 5. Normalisasi Index Kenyamanan Kota Yogyakarta berdasarkan Kriteria Pelestarian BCB

\begin{tabular}{|c|c|c|c|c|c|c|c|c|}
\hline \multirow[b]{2}{*}{ No } & \multirow[b]{2}{*}{$\mathrm{KCB}$} & \multicolumn{5}{|c|}{ Variabel Indeks Kenyamanan Berdasarkan Kriteria Pelestarian BCB } & \multirow[b]{2}{*}{$\begin{array}{l}\text { Total } \\
\text { Nilai } \\
\text { Index }\end{array}$} & \multirow[b]{2}{*}{$\begin{array}{l}\text { Nilai } \\
\text { Index } \\
(\%)\end{array}$} \\
\hline & & $\begin{array}{l}\text { Perubahan } \\
\text { Bentuk } \\
\text { Bangunan }\end{array}$ & $\begin{array}{l}\text { Perubahan } \\
\text { Fungsi } \\
\text { Bangunan }\end{array}$ & $\begin{array}{l}\text { Status } \\
\text { Kepemilikan } \\
\text { Bangunan }\end{array}$ & $\begin{array}{l}\text { Status } \\
\text { Penggunaan } \\
\text { Bangunan }\end{array}$ & $\begin{array}{l}\text { BCB yang } \\
\text { Dihancurkan/ } \\
\text { Proses } \\
\text { Penghancuran }\end{array}$ & & \\
\hline 1 & Malioboro & 100 & 10 & 10 & 100 & 100 & 320 & 64 \\
\hline 2 & Kotabaru & 100 & 40 & 20 & 100 & 100 & 360 & 72 \\
\hline 3 & Pakualaman & 100 & 25 & 50 & 100 & 100 & 325 & 65 \\
\hline 4 & Kraton & 100 & 14.3 & 35.7 & 100 & 100 & 321.43 & 64.3 \\
\hline 5 & Kotagede & 87.1 & 9.7 & 83.9 & 96.8 & 96.8 & 303.23 & 60.6 \\
\hline \multicolumn{2}{|c|}{ TOTAL } & & & & & & 500 & \\
\hline
\end{tabular}

Sumber: Hasil Analisis, 2018

Asumsi pemberian nilai index kenyamanan tertinggi adalah 100 dan terendah adalah 10. Maka pembagian skoring/pembobotannya adalah indeks kenyamanan tinggi bernilai 100-70, sedang/cukup bernilai 70-40 dan rendah bernilai 40-10. Apabila dilihat dari analisis yang telah dilakukan, dapat diketahu bahwa nilai indeks kenyamanan di lima KCB Kota Yogkarta dalam upaya perlindungan bangunan cagar budaya tergolong tinggi dan cukup tinggi dengan nilai berkisar $72 \%-60,6 \%$. Hal ini telah sesuai dengan hasil perhitungan IAP yang menempatkan Kota Yogyakarta sebagai kota ternyaman dalam pelestarian bangunan cagara budaya di Indonesia.

Dari tabel diatas, dapat diperoleh hasil bahwa nilai index kenyamanan tertinggi dalam pelestarian bangunan cagar budaya adalah Kawasan Cagar Budaya Kotabaru dengan prosentase nilai index kenyamanannya $72 \%$, kemudian Kawasan Cagar Budaya Pakualaman dengan 64,3\%; Kawasan Cagar Budaya Kraton dengan 64\%; Kawasan Cagar Budaya Malioboro dengan $64 \%$ dan yang memiliki nilai prosentase index kenyamanan terendah adalah Kawasan Cagar Budaya Kotagede dengan nilai index kenyamanan 60.6\%. Berikut merupakan penjelasan rincian perolehan hasil:

\section{Kawasan Cagar Budaya Kotabaru}

Sampel bangunan cagar budaya yang berada di KCB Kotabaru adalah 5 bangunan, dengan jumlah populasi BCB mencapai 16 bangunan. Dari 5 bangunan, sebanyak 5 bangunan tidak mengalami perubahan bentuk, baik itu mendirikan bangunan, memperluas, mengubah, mengurangi maupun memugar BCB (Dinas Perizinan dan Penanaman Modal DIY, 2018). Untuk variabel perubahan fungsi hanya 2 bangunan yang merubah fungsinya dari rumah tinggal pribadi menjadi pemerintahan (Kantor Dinas Pariwisata Kota Yogyakarta) dan kantor (PT. Sarana Yogya Ventura). Variabel status kepemilikan sebanyak 1 bangunan merupakan hak milik pribadi dan 9 bangunan merupakan sewa, dimana hal ini disebabkan kepemilikan tanah dan bangunan merupakan pemerintah Kota Yogyakarta. Sedikitnya 
bangunan milik pribadi juga didukung oleh status penggunaan lahan yaitu 5 BCB digunakan secara kelompok. Penggunaan secara kelompok ini merupakan bangunan dengan fungsi fasiitas umum, perdagangan jasa dan restoran. Untuk variabel bangunan yang dihancurkan, sebanyak 5 bangunan tidak melakukan penghancuran atau dalam proses penghancuran, karena seluruh bangunan tidak melakukan perubahan bentuk BCB.

Dari penjelasan diatas, dapat disimpulkan bahwa KCB Kotabaru memiliki indeks kenyamanan tipologi 1 (paling tinggi) untuk upaya pelestarian bangunan cagar budaya karena $100 \%$ BCB tidak mengalami perubahan bentuk sehingga tidak melanggar aturan pelestarian dari pemerintahan daerah DIY (Perda, 2012), 40\% BCB mengalami perubahan fungsi sehingga upaya peningkatan pemanfaatan bangunan tergolong tinggi, $20 \% \mathrm{BCB}$ merupakan milik pribadi sehingga rasa keeratan pemilik dengan bangunan cagar budaya sebagai identitas kehidupan sosial masih kurang yang dikhawatirkan akan mempermudah pengguna bangunan untuk mengubah $\mathrm{BCB}$, sebanyak $100 \%$ BCB dipergunakan untuk kelompok/umum sehingga alokasi dana untuk melakukan pelestarian $\mathrm{BCB}$ tergolong tinggi, serta sebanyak 100\% BCB tidak dihancurkan dan/atau dalam proses penghancuran sehingga bentuk asli BCB masih bisa dipertahankan dan ini merupakan salah satu upaya pelestarian.

Berdasarkan Kleden \& Fanani (2016) disebutkan bahwa Kawasan Cagar Budaya Kotabaru memiliki bangunan bercorak kolonial sehingga dilarang untuk diubah menjadi fasad Jawa, atau bentuk lain yang tak mencermikan fasad khas indiesch. Hal ini telah sesuai dengan hasil survey, dimana disebutkan $100 \%$ bangunan cagar budaya di KCB Kotabaru tidak mengalami perubahan bentuk dan tidak dalam proses penghancuran. Perubahan fungsi yang dilakukan diperbolehkan selama tidak merubah bentuk fasade bangunan cagar budaya (Djunaidi, dkk, 2015).
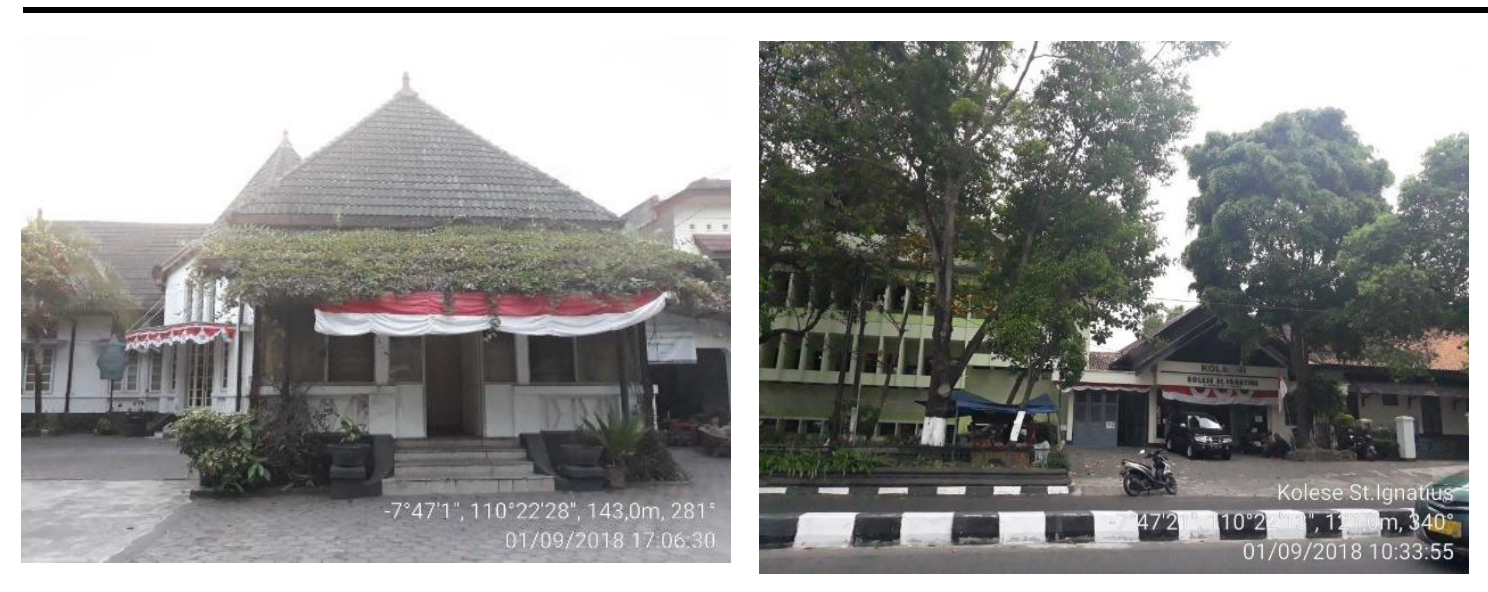

Sumber : Survei Lapangan, 2018

\section{Gambar 2. Bangunan Cagar Budaya di Kawasan Cagar Budaya Kota Baru. Bangunan Cagar Budaya yang mengalami perubahan fungsi (Kiri)}

\section{Kawasan Cagar Budaya Pakualaman}

Sampel bangunan cagar budaya yang berada di KCB Pakualaman adalah 8 bangunan, dengan jumlah populasi BCB mencapai 21 bangunan. Dari 8 bangunan, sebanyak 8 bangunan tidak mengalami perubahan bentuk, baik itu mendirikan bangunan, memperluas, mengubah, mengurangi maupun memugar BCB (Dinas Perizinan dan Penanaman Modal 
DIY, 2018). Untuk variabel perubahan fungsi hanya 2 bangunan yang merubah fungsinya dari rumah tinggal menjadi restauran dan hotel. Variabel status kepemilikan sebanyak 4 bangunan merupakan hak milik pribadi dan 4 bangunan merupakan sewa, dimana hal ini disebabkan kepemilikan tanah dan bangunan merupakan milik kesultanan Yogyakarta. Sebanyak 4 bangunan dipergunakan secara kelompok dan sisanya digunakan untuk pribadi, yang dominannya dipergunakan sebagai rumah tinggal. Sedangkan penggunaan secara kelompok merupakan bangunan dengan fungsi fasiitas umum, perdagangan jasa dan hotel. Untuk variabel bangunan yang dihancurkan sebanyak 8 bangunan tidak melakukan penghancuran atau dalam proses penghancuran, karena seluruh bangunan tidak melakukan perubahan bentuk BCB.

Dari penjelasan diatas, dapat disimpulkan bahwa KCB Pakualaman memiliki indeks kenyamanan tipologi 2 untuk upaya pelestarian bangunan cagar budaya karena $100 \%$ BCB tidak mengalami perubahan bentuk sehingga tidak melanggar aturan pelestarian dari pemerintahan daerah DIY (Perda, 2012), 25\% BCB mengalami perubahan fungsi sehingga upaya peningkatan pemanfaatan bangunan tergolong cukup tinggi, 50\% BCB merupakan milik pribadi sehingga rasa keeratan pemilik dengan bangunan cagar budaya sebagai identitas kehidupan sosial masih tergolong cukup tinggi sehingga diharapkan dengan eratnya rasa kepemilikan, maka perubahan bentuk bangunan dapat diminimalisir, sebanyak $50 \%$ $\mathrm{BCB}$ dipergunakan untuk kelompok/umum sehingga alokasi dana untuk melakukan pelestarian BCB masih tergolong cukup tinggi, serta sebanyak 100\% BCB tidak dihancurkan dan/atau dalam proses penghancuran sehingga bentuk asli BCB masih bisa dipertahankan dan ini merupakan salah satu upaya pelestarian.
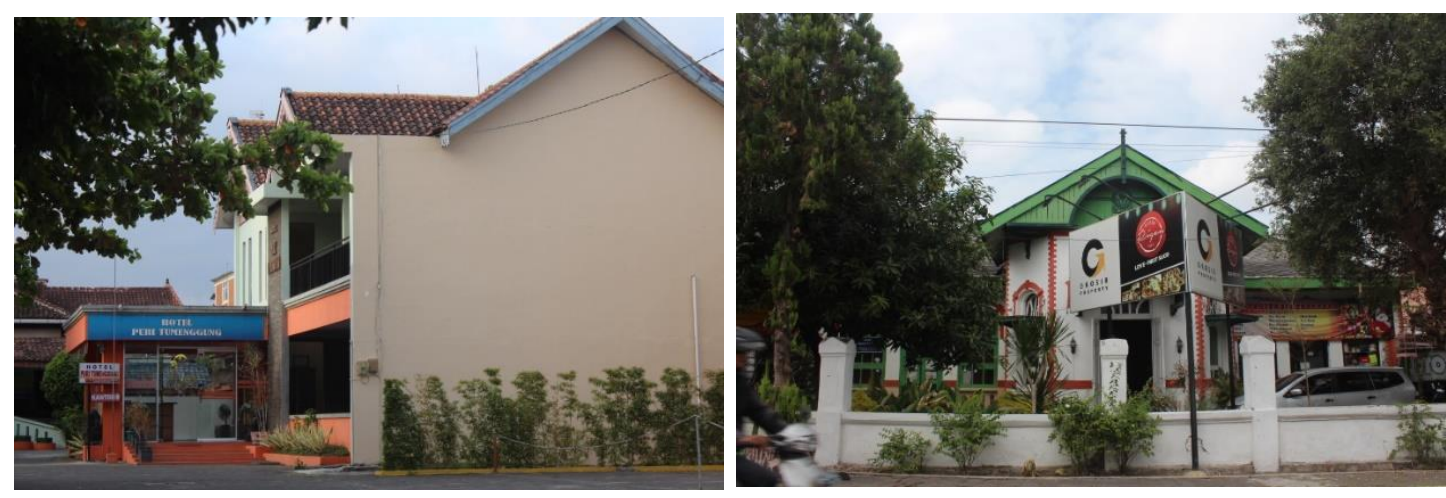

Sumber : Survei Lapangan, 2018

Gambar 3. Perubahan Fungsi Bangunan Cagar Budaya di Kawasan Cagar Budaya Pakualaman

\section{Kawasan Cagar Budaya Kraton}

Sampel bangunan cagar budaya yang berada di KCB Kraton adalah 14 bangunan, dengan jumlah populasi BCB mencapai 43 bangunan. Dari 14 bangunan, sebanyak 14 bangunan tidak mengalami perubahan bentuk, baik itu mendirikan bangunan, memperluas, mengubah, mengurangi maupun memugar BCB (Dinas Perizinan dan Penanaman Modal DIY, 2018). Untuk variabel perubahan fungsi hanya 2 bangunan yang merubah fungsinya dari rumah tinggal menjadi perdagangan (restauran). Variabel status kepemilikan sebanyak 5 bangunan merupakan hak milik pribadi dan 9 bangunan merupakan sewa, dimana hal ini disebabkan kepemilikan tanah dan bangunan merupakan milik kesultanan Yogyakarta. Sedikitnya bangunan milik pribadi juga didukung oleh sedikitnya guna bangunan personal yaitu hanya 4 BCB sedangkan 10 BCB digunakan secara kelompok. Penggunaan secara kelompok ini merupakan bangunan dengan fungsi fasiitas umum dan restauran. Untuk 
variabel bangunan yang dihancurkan sebanyak 14 bangunan tidak melakukan penghancuran atau dalam proses penghancuran, karena seluruh bangunan tidak melakukan perubahan bentuk BCB.

Dari penjelasan diatas, dapat disimpulkan bahwa KCB Kraton memiliki indeks kenyamanan tipologi 3 untuk upaya pelestarian bangunan cagar budaya karena 100\% BCB tidak mengalami perubahan bentuk sehingga tidak melanggar aturan pelestarian dari pemerintahan daerah DIY (Perda, 2012), 14,3\% BCB mengalami perubahan fungsi sehingga upaya peningkatan pemanfaatan bangunan tergolong rendah, 35,7\% BCB merupakan milik pribadi sehingga rasa keeratan pemilik dengan bangunan cagar budaya sebagai identitas kehidupan sosial tergolong rendah sehingga dikhawatirkan akan meningkatkan jumlah BCB yang mengalami perubahan bentuk/dihancurkan, sebanyak 71,4\% BCB dipergunakan untuk kelompok/umum sehingga alokasi dana untuk melakukan pelestarian BCB masih tergolong tinggi, serta sebanyak $100 \%$ BCB tidak dihancurkan dan/atau dalam proses penghancuran sehingga bentuk asli BCB masih bisa dipertahankan dan ini merupakan salah satu upaya pelestarian.

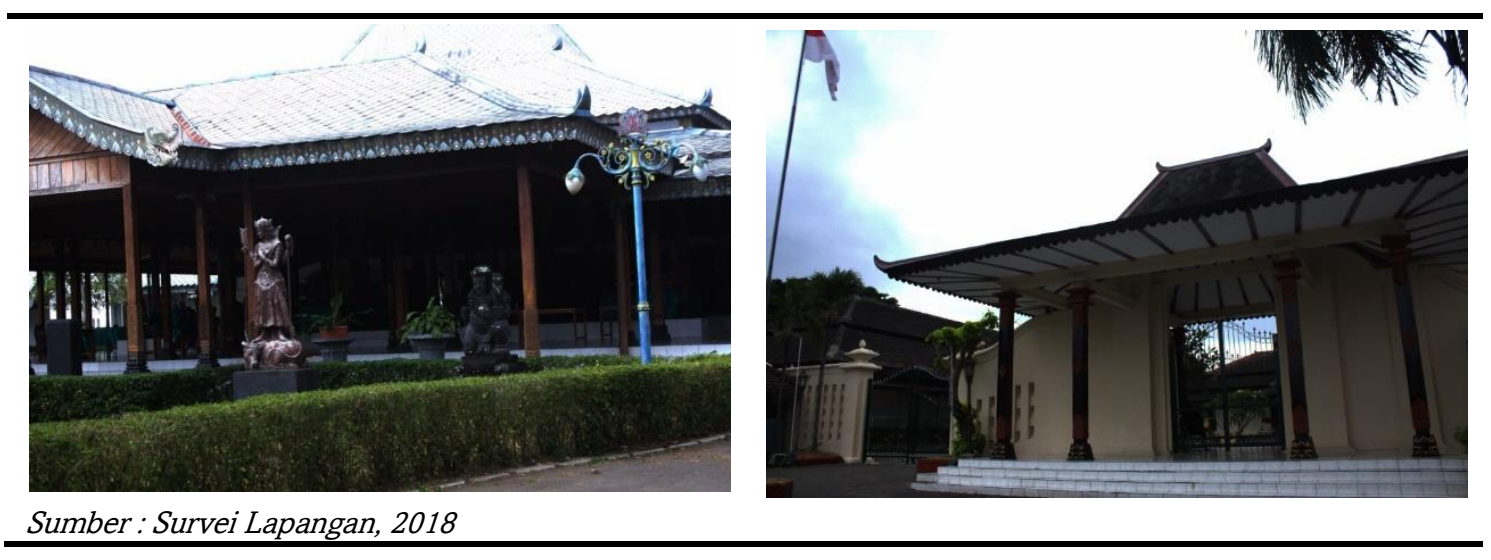

Gambar 4. Perubahan Fungsi Bangunan Cagar Budaya di Kawasan Cagar Budaya Kraton

\section{Kawasan Cagar Budaya Malioboro}

Sampel bangunan cagar budaya yang berada di KCB Malioboro adalah 10 bangunan, dengan jumlah populasi BCB mencapai 32 bangunan. Dari 10 bangunan, sebanyak 10 bangunan tidak mengalami perubahan bentuk, baik itu mendirikan bangunan, memperluas, mengubah, mengurangi maupun memugar BCB (Dinas Perizinan dan Penanaman Modal DIY, 2018). Untuk variabel perubahan fungsi hanya 1 bangunan yang merubah fungsinya dari rumah tinggal pribadi menjadi rumah kos-kosan. Variabel status kepemilikan sebanyak 1 bangunan merupakan hak milik pribadi dan 9 bangunan merupakan sewa, dimana hal ini disebabkan kepemilikan tanah dan bangunan merupakan milik kesultanan Yogyakarta. Sedikitnya bangunan milik pribadi juga didukung oleh guna bangunan personal yaitu $10 \mathrm{BCB}$ digunakan secara kelompok. Penggunaan secara kelompok ini merupakan bangunan dengan fungsi fasiitas umum, perdagangan jasa dan restauran. Untuk variabel bangunan yang dihancurkan sebanyak 10 bangunan tidak melakukan penghancuran atau dalam proses penghancuran, karena seluruh bangunan tidak melakukan perubahan bentuk BCB.

Dari penjelasan diatas, dapat disimpulkan bahwa KCB Malioboro memiliki indeks kenyamanan tipologi 4 untuk upaya pelestarian bangunan cagar budaya karena 100\% BCB tidak mengalami perubahan bentuk sehingga tidak melanggar aturan pelestarian dari pemerintahan daerah DIY (Perda, 2012), 10\% BCB mengalami perubahan fungsi sehingga upaya peningkatan pemanfaatan bangunan tergolong rendah, 10\% BCB merupakan milik 
pribadi sehingga rasa keeratan pemilik dengan bangunan cagar budaya sebagai identitas kehidupan sosial tergolong rendah yang dikhawatirkan akan meningkatkan jumlah BCB yang mengalami perubahan bentuk/dihancurkan, sebanyak 100\% BCB dipergunakan untuk kelompok/umum sehingga alokasi dana untuk melakukan pelestarian $\mathrm{BCB}$ tergolong tinggi, serta sebanyak $100 \%$ BCB tidak dihancurkan dan/atau dalam proses penghancuran sehingga bentuk asli BCB masih bisa dipertahankan dan ini merupakan salah satu upaya pelestarian.

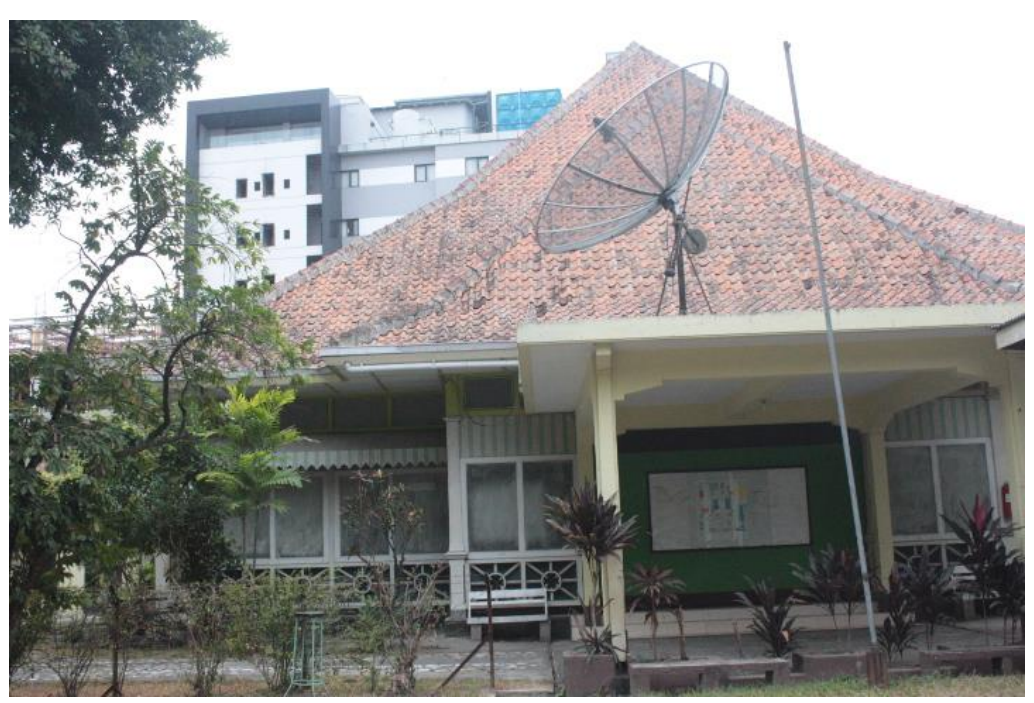

Sumber : Survei Lapangan, 2018

Gambar 5. Perubahan Fungsi Bangunan Cagar Budaya di Kawasan Cagar Budaya Malioboro

\section{Kawasan Cagar Budaya Kotagede}

Sampel bangunan cagar budaya yang berada di KCB Kotagede adalah 31 bangunan, dengan jumlah populasi BCB mencapai 96 bangunan. Dari 31 bangunan, sebanyak 27 bangunan tidak mengalami perubahan bentuk dan 4 bangunan mengalami perubahan bentuk disebabkan terjadinya bencana gempa yang menyebabkan bangunan rubuh sehingga mendirikan bangunan baru atau memang mengubah menjadi bangunan baru dengan alasan estetika. Untuk variabel perubahan fungsi hanya 3 bangunan yang merubah fungsinya dari rumah tinggal menjadi perdagangan dan jasa serta fungsi pemerintahan (Dinas Kebudayaan Kota Yogyakarta). Variabel status kepemilikan sebanyak 26 bangunan merupakan hak milik pribadi dan 5 bangunan merupakan sewa, dimana hal ini juga dipengaruhi oleh banyaknya fungsi peruntukan $\mathrm{BCB}$ sebagai rumah tinggal. Banyaknya bangunan milik pribadi juga didukung oleh banyaknya guna bangunan secara personal yaitu 29 BCB sedangkan 8 BCB digunakan secara kelompok. Variabel bangunan yang dihancurkan sebanyak 30 bangunan tidak melakukan penghancuran atau dalam proses penghancuran, sedangkan sisanya sebanyak 1 bangunan melakukan penghancuran karena bencana gempa yang merobohkan bangunan cagar budaya.

Dari penjelasan diatas, dapat disimpulkan bahwa KCB Kotagede memiliki indeks kenyamanan tipologi 5 (terendah) untuk upaya pelestarian bangunan cagar budaya karena $87,1 \%$ BCB tidak mengalami perubahan bentuk sehingga masih ada sekitar 12,9\% BCB telah melanggar aturan pelestarian dari pemerintahan daerah DIY (Perda, 2012), 9,7\% BCB mengalami perubahan fungsi sehingga upaya peningkatan pemanfaatan bangunan tergolong rendah, $83,9 \%$ BCB merupakan milik pribadi sehingga rasa keeratan pemilik dengan 
bangunan cagar budaya sebagai identitas kehidupan sosial tergolong tinggi yang berdampak pada jumlah bangunan cagar budaya yang mengalami perubahan bentuk, sebanyak $25,8 \%$ $\mathrm{BCB}$ dipergunakan untuk kelompok/umum sehingga alokasi dana untuk melakukan pelestarian $\mathrm{BCB}$ tergolong rendah, serta sebanyak 96,8\% BCB tidak dihancurkan dan/atau dalam proses penghancuran sehingga bentuk asli $\mathrm{BCB}$ masih bisa dipertahankan dan ini merupakan salah satu upaya pelestarian.
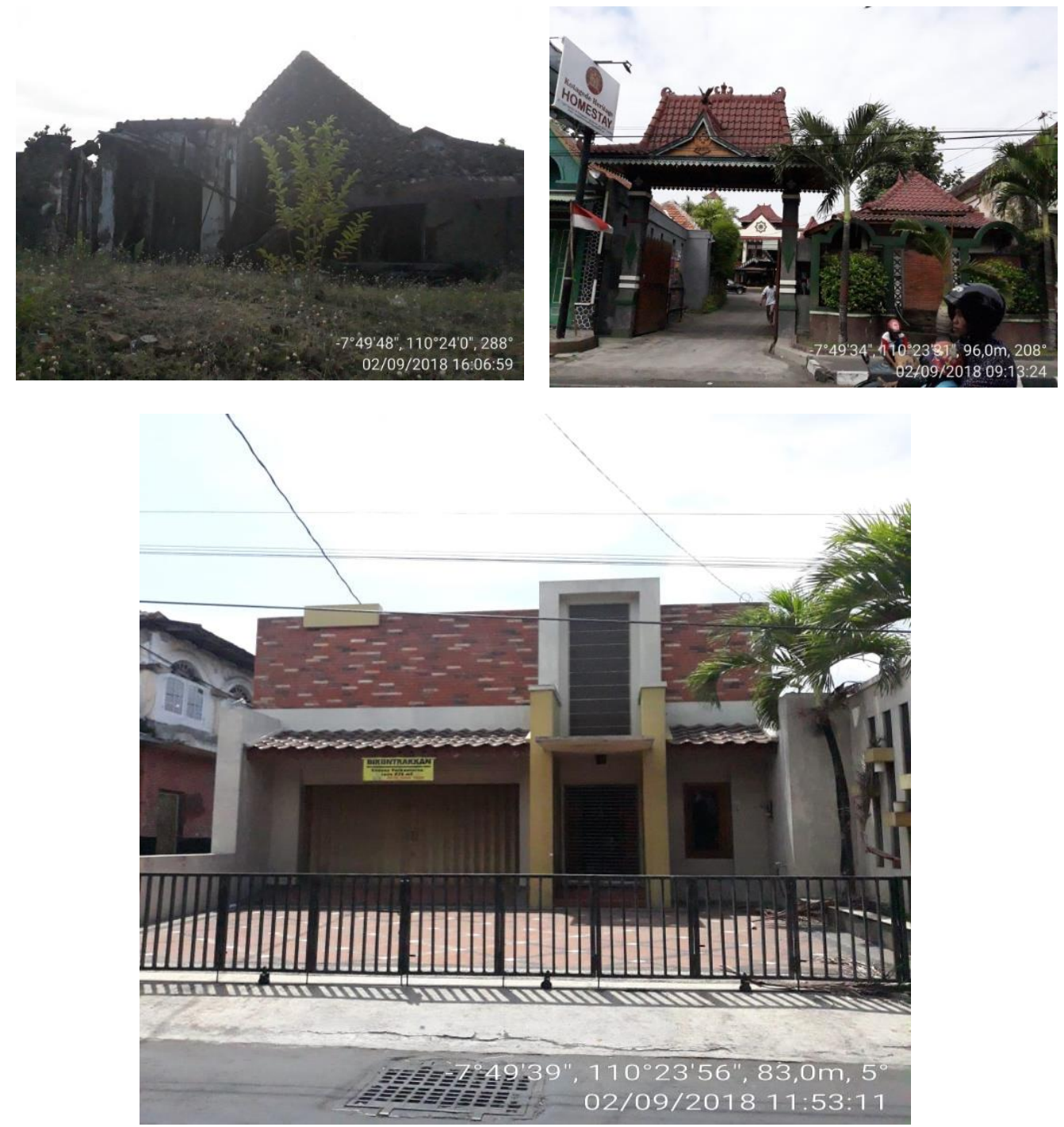

Sumber : Survei Lapangan, 2018

Gambar 6. Perubahan Bentuk Bangunan Cagar Budaya (Kiri dan Kanan Bawah) dan Perubahan Fungsi Tempat Tinggal menjadi Fungsi Jasa (Kanan Atas) di Kawasan Cagar Budaya Kotagede

Berdasarkan penelitian yang telah peneliti teliti sebelumnya, diperoleh hasil bahwa upaya pelestarian bangunan cagar budaya di Kota Yogyakarta dalam kondisi baik, dimana hampir $80 \%$ responden mengatakan bahwa upaya pelestarian di masing-masing kawasan cagar budaya telah berjalan. Hal ini terlihat dari upaya pelestarian oleh pemerintah kota Yogyakarta, seperti penyusunan dokumen pedoman pelestarian kawasan cagar budaya, pemberian insentif kepada pemilik bangunan cagar budaya, pemeliharaan bangunan cagar 
budaya dengan SK Menteri yang dilakukan dengan bantuan negara (Balai Pelestarian Cagar Budaya DIY), dan terdapat tim pengkaji bangunan bersejarah/kuno sebelum ditetapkan sebagai bangunan cagar budaya. Upaya pemerintah tersebut juga didukung oleh pemilik/pengguna bangunan cagar budaya dimana hampir $80 \%$ mengatakan bahwa kondisi pelestarian di masing-masing kawasan cagar budaya dalam kondisi bagus (survey primer, 2018). Tidak terjadinya perubahan bentuk bangunan juga didukung oleh upaya pelestarian Kota Yogyakarta berupa Peraturan Menteri Pekerjaan Umum No 20/PRT/M/2011 tentang Rencana Detail Tata Ruang Kota, dimana ketika satu zona yang tidak memiliki bangunan cagar budaya harus menyesuaikan dengan ketentuan atau aturan yang sama seperti zona yang memiliki bangunan cagar budaya (Kleden \& Fanani, 2016).

\section{KESIMPULAN DAN REKOMENDASI}

Keberadaan bangunan cagar budaya di suatu kota akan menambah nilai identitas lingkungan yang merupakan penciri kawasan dan karakteristik masyarakat yang tinggal didalamnya. Nilai indeks kenyamanan di Kota Yogyakarta untuk kriteria pelestarian bangunan cagar budaya tertinggi berada di kawasan cagar budaya Kotabaru (72\%), kemudian kawasan cagar budaya Pakualaman (65\%), kawasan cagar budaya Kraton $(64,3 \%)$, selanjutnya kawasan cagar budaya Malioboro (64\%) dan terendah adalah kawasan cagar budaya Kogede (60,6\%). Kawasan cagar budaya Kotabaru memiliki indeks kenyamanan tertinggi karena sebanyak 100\% BCB tidak mengalami perubahan bentuk, 40\% $\mathrm{BCB}$ mengalami perubahan fungsi (dimana untuk variabel ini, Kotabaru memiliki nilai prosentase tertinggi dibandingkan KCB lainnya), 20\% BCB merupakan milik pribadi, $100 \%$ $\mathrm{BCB}$ dipergunakan untuk kelompok/umum dan 100\% BCB tidak dihancurkan dan/atau dalam proses penghancuran sehingga bentuk asli BCB masih bisa dipertahankan. Variabel perubahan fungsi akan menambah nilai bangunan cagar budaya, sedangkan perubahan bentuk akan mengurangi nilai bangunan cagar budaya. Variabel kepemilikan bangunan cagar budaya akan memberikan nilai tambah apabila berupa milik pribadi karena akan menambah ikatan atas identitas pemilik. Sedangkan untuk variabel pengguna bangunan akan memberikan nilai tambah apabila dipergunakan secara bersama/kelompok, karena akan mempermudah dalam membayar biaya perawatan bangunan cagar budaya. Faktor bencana alam dan ekonomi bisa menjadi salah satu alasan pemilik bangunan untuk merubah bentuk $\mathrm{BCB}$, ditunjang oleh kurangnya bantuan pemerintah kota untuk membantu dalam menyediakan dana perawatan $\mathrm{BCB}$.

\section{UCAPAN TERIMA KASIH}

Penulis mengucapkan terima kasih kepada Kementerian Riset, Teknologi, dan Pendidikan Tinggi yang telah mendanai penelitian ini melalui Hibah Penelitain Dosen Pemula Tahun Anggaran 2018. Terima kasih juga ditujukan kepada STTNAS dan pemerintah Kota Yogyakarta serta Balai Pelestarian Cagar Budaya atas dukungan dan bantuan yang diberikan selama proses penelitian.

\section{DAFTAR PUSTAKA}

Bell, Karen. 2000. Urban Amenity Indicators: The Livability of Our Urban Environments. Ministry for the Environment of Auckland City.

Darise D.I, Tondobala L, Gosal P.H.2015. Kajian Kota Manado sebagai Kota Layak Huni berdasarkan Kriteria (IAP) Ikatan Ahli Perencanaan. [Skripsi]: Universitas Sam Ratulangi. 1(1): 131-140.

Dinas Perizinan dan Penanaman Modal DIY, 2018

Hadiyanta Ign, Eka. 2015. Kawasan Cagar Budaya di Yogyakarta: Citra, Identitas, dan Branding Ruang. Yogyakarta: Jurnal Widya Prabha. Vol. 04/ IV/ 2015 
Ikatan Ahli Perencanaan (IAP). 2016. The Most Liveable City in Indonesia. https://www.issuu.com/iapindonesia/docs/mlci 2014 presentasi compatibility. Diakses pada 03 Juni 2017

Kladen U.C, Fanani F. 2016. Harmonisasi Ketentuan Peruntukan Bangunan Cagar Budaya dalam Perspektif Regulasi di Kawasan Budaya Kotabaru, Kota Yogyakarta-DIY. Jurnal ReTII STTNAS. ISSN: 1907-5995. Yogyakarta

Marbun J. 2012. Pelestarian Benda dan Bangunan Cagar Budaya di Yogyakarta. https://joemarbun.wordpress.com/permasalahan-kawasan-cagar-budaya. Diakses pada 28 April 2018

Muttaqin D. 2010. Most Livable City Index, Tantangan Menuju Kota Layak Huni. Bulletin Tata Ruang Edisi Januari-Februari 2010. ISSN: 1978-1571. Jakarta: Badan Koordinasi Penataan Ruang Nasional.

Pemerintah Kota Yogyakarta. 2017. Visi dan misi Kota Yogyakarta. Diakses pada 28 Agustus 2018 dari https://jogjaprov.go.id/profil/4-visi-misi-tujuan-dan-sasaran

Peraturan Daerah Provinsi Daerah Istimewa Yogyakarta No 10 Tahun 2012 tentang Pelestarian Warisan Budaya dan Cagar Budaya. Yogyakarta

Peraturan Gubernur Daerah Istimewa Yogyakarta Nomor 62 Tahun 2013 tentang Pelestarian Cagar Budaya. (2013).

Sujarweni, Wiranta. 2015. SPPS untuk Penelitian. Pustaka Baru Press. Yogyakarta

Tan, Thye, et all. 2014. A New Approach to Measuring the Liveability of Cities: the Global Liveable Cities Index. World Review of Science, Technology and Sustainable Development. Vol 11, No.2, 2014.

Undang-Undang Nomor 5 Tahun 1992, tentang Benda dan Bangunan Cagar Budaya.

Wahyudi D. 2012. Kepemilikan Benda Cagar Budaya (Antara Kewajiban dan Hak). http://pusakanuswantara.blogspot.com/2012/10/kepemilikan-benda-cagar-budaya-antara.html. Diakses 27 Mei 2018

Wheleer, Stephen. 2004. The Sustainable Urban Development Reader. Psychological Press. New York

Widyanto, Andreas Haryo. 2016. Perizinan pemanfaatan bangunan cagar budaya untuk bisnis waralaba London Beauty Center (LBC) di Kota Yogyakarta. Diakses pada 27 Agustus 2018 dari http://ejournal.uajy.ac.id/id/eprint/11582.

Wirastari, Amanda \& Suprihardjo, Rimadewi. 2012. Pelestarian keawasan cagar budaya berbasis partisipasi masyarakat (studi kasus: kawasan cagar budaya Bubutan, Surabaya). Jurnal teknik ITS, 1(1), 63-67 